\title{
Coking on micrometer- and nanometer-sized mordenite during dimethyl ether carbonylation to methyl acetate
}

\author{
Huifu Xue a, Xiumin Huang a, Evert Ditzel b, Ensheng Zhan a, Meng Ma a, Wenjie Shen a,* \\ a State Key Laboratory of Catalysis, Dalian Institute of Chemical Physics, Chinese Academy of Sciences, Dalian 116023, Liaoning, China \\ ${ }^{\mathrm{b}}$ Hull Research and Technology Centre, BP Chemicals Limited, Hull HU128DS, UK
}

A R T I C L E I N F O

Article history:

Received 25 March 2013

Accepted 26 April 2013

Published 20 August 2013

\section{Keywords:}

H-mordenite

Dimethyl ether

Carbonylation

Crystal size

Coking

\begin{abstract}
A B S T R A C T
As compared to conventional micrometer-sized mordenite particles, nanometer-sized mordenite gave a much higher activity and better stability in dimethyl ether carbonylation to methyl acetate by suppressing the deposition of hard coke. A structural analysis revealed that intra-crystalline diffusion limitation of the reactants and products to and from the active sites inside the channels was greatly decreased by reducing the zeolite size to the nanometer size.
\end{abstract}

(C) 2013, Dalian Institute of Chemical Physics, Chinese Academy of Sciences. Published by Elsevier B.V. All rights reserved.

\section{Introduction}

Ethanol can be used by itself or blended with gasoline as an alternative motor fuel. Dimethyl ether (DME) carbonylation to methyl acetate (MA) is viewed as a crucial step in the use of syngas to make ethanol. In this reaction, DME initially reacts with CO to form MA on a solid zeolite, which is followed by the hydrogenation of MA to ethanol over supported copper catalysts [1-3]. H-mordenite (HMOR) is the most active catalyst for DME carbonylation to MA [4-14], but the HMOR catalysts suffered severe deactivation due to the heavy deposition of carbonaceous species during reaction. Mordenite has a two dimensional framework structure consisting of straight 12 -membered ring $(12-\mathrm{MR})$ pores $(0.67 \mathrm{~nm} \times 0.70 \mathrm{~nm})$ that are connected by twisted $(0.28 \mathrm{~nm} \times 0.57 \mathrm{~nm}$, side pockets along (001) crystal facet) and crossed $(0.34 \mathrm{~nm} \times 0.48 \mathrm{~nm}$, along (010) crystal facet) 8 -membered ring $(8-\mathrm{MR})$ pores $[14,15]$.
DME carbonylation mainly occurs in the 8-MR crossed pores, which have the unique orientation to stabilize the $\mathrm{CH}_{3} \mathrm{CO}^{*}$ intermediate of the methoxy groups $[7,8,14]$. However, side reactions that take place in the 12-MR pores lead to the formation of coke. For example, surface methoxy groups in the 12-MR channels react more rapidly with DME to produce large hydrocarbons [14]. This is due to the slow diffusion in the zeolite channels. Therefore, it should be possible to suppress coke formation in the 12-MR channels of HMOR by facilitating the diffusion process.

Two primary strategies have been proposed to lower diffusion resistance and enhance mass transfer: one is to create mesopores within the zeolite crystals [16-18], and the other is to reduce the crystallite size to the nanometer size [19-27]. In fact, nanometer-sized zeolites have been shown to greatly reduce the diffusion resistance and dramatically suppress coke deposition [28]. Reducing the crystalline size from the typical

\footnotetext{
*Corresponding author. Tel: +86-411-84379085; Fax: +86-411-84694447; E-mail: shen98@dicp.ac.cn This work was supported by the National Basic Research Program of China (2013CB933100) and the National Natural Science Foundation of China (20973166). 
micrometer scale to the nanometer level shortens the diffusion pathway. For example, decreasing the size of HZSM-5 to about $100 \mathrm{~nm}$ has remarkably enhanced its catalytic stability in $n$-hexane cracking $[22,27]$ and in the processes of reacting acetone to olefin $[23,25]$, methanol to gasoline [21,26], and methanol to DME [24]. Nanometer-sized beta zeolites (80-100 nm) also exhibited higher activity and stability than those of conventional large particles $(2-4 \mu \mathrm{m})$ in the acylation of anisole and toluene [20]. In this work, we compared DME carbonylation over nanometer-sized with commercial micrometer mordenites to elucidate the role of crystal size on activity and stability.

\section{Experimental}

\subsection{Synthesis of HMOR catalysts}

The nanometer-sized HMOR (HMOR-N) was synthesized by a hydrothermal process [29]. $\operatorname{Al}\left(\mathrm{NO}_{3}\right)_{3} \cdot 9 \mathrm{H}_{2} \mathrm{O}(2.71 \mathrm{~g})$ and Et 6 -diquat-5 $\quad\left(N, N, N, N^{\prime}, N^{\prime}, N^{\prime}\right.$-hexaethylpentanediammonium cations, $4.7 \mathrm{~g}$ ) were dissolved into $60 \mathrm{ml} \mathrm{NaOH}$ aqueous solution $(1.0 \mathrm{~mol} / \mathrm{L})$, followed by the addition of $21.28 \mathrm{~g}$ silica sol. The mixture was stirred at room temperature for $24 \mathrm{~h}$ and then transferred into a Teflon-lined autoclave $(100 \mathrm{ml})$. After crystallization at $433 \mathrm{~K}$ for $7 \mathrm{~d}$ under stirring, the solid product was filtrated, washed thoroughly with water, dried at $383 \mathrm{~K}$ for 12 $\mathrm{h}$, and finally calcined at $823 \mathrm{~K}$ for $8 \mathrm{~h}$ in air. The solid obtained was ion exchanged with $\mathrm{NH}_{4} \mathrm{NO}_{3}$ aqueous solution (1.0 mol/L) at $353 \mathrm{~K}$ for $12 \mathrm{~h}$ [4]. The resulting sample was dried at $383 \mathrm{~K}$ for $12 \mathrm{~h}$ and calcined at $773 \mathrm{~K}$ for $3 \mathrm{~h}$ in air to give the HMOR-N catalyst.

The conventional micrometer-sized mordenite (HMOR-C) was prepared by the ion exchange of a commercial Na-type mordenite. Na-mordenite ( $\mathrm{Si} / \mathrm{Al}$ molar ratio of 9, $10 \mathrm{~g}$ ) was ion exchanged sequentially four times with $400 \mathrm{ml} \mathrm{NH}_{4} \mathrm{NO}_{3}(1.0$ $\mathrm{mol} / \mathrm{L}$ ) at $353 \mathrm{~K}$ for $12 \mathrm{~h}$ and dried at $383 \mathrm{~K}$ for $12 \mathrm{~h}$. The dried sample ( $4 \mathrm{~g}$ ) was then treated with $\mathrm{HNO}_{3}$ solution $(200 \mathrm{ml}, 4.0$ $\mathrm{mol} / \mathrm{L}$ ) at $373 \mathrm{~K}$ for $10 \mathrm{~h}$ in order to mediate the Si/Al molar ratio. After filtration and washing with water, the solid was dried at $383 \mathrm{~K}$ overnight and calcined at $773 \mathrm{~K}$ for $6 \mathrm{~h}$ in air to give the HMOR-C catalyst.

\subsection{Characterization}

X-ray diffraction (XRD) patterns were recorded on a Rigaku D/MAX-2500/PC X-ray diffractometer using a $\mathrm{Cu} K_{\alpha}$ radiation operated at $40 \mathrm{kV}$ and $200 \mathrm{~mA}$. $\mathrm{N}_{2}$ adsorption isotherms were obtained at $77 \mathrm{~K}$ using a Quantachrome Autosorb-1-MP gas sorption analyzer. Before the measurements, the samples were degassed at $573 \mathrm{~K}$ for $2 \mathrm{~h}$. Field emission scanning electron microscopy (FE-SEM) images were recorded using a Philips FEI Quanta 200F microscope operated at $20 \mathrm{kV}$. Samples were placed on a conductive carbon tape affixed on an aluminum sample holder. Transmission electron microscopy (TEM) images were recorded using a FEI Tecnai G2 Spirit microscope operated at $120 \mathrm{kV}$. The specimen was prepared by ultrasonically dispersing the samples in ethanol, and using this suspen- sion droplets were deposited on a carbon-enhanced copper grid and dried in air.

Temperature-programmed desorption of ammonia ( $\mathrm{NH}_{3}$-TPD) experiments were conducted with a U-shape quartz tube reactor. A $100 \mathrm{mg}$ sample was heated to $773 \mathrm{~K}$ at a rate of $10 \mathrm{~K} / \mathrm{min}$ and maintained at that temperature for $1 \mathrm{~h}$ under $\mathrm{He}$ flow (30 ml/min). The sample was then purged with a $10 \%$ $\mathrm{NH}_{3} / \mathrm{He}$ mixture $(30 \mathrm{ml} / \mathrm{min}$ ) for $30 \mathrm{~min}$ at $473 \mathrm{~K}$. Physically adsorbed ammonia was removed by purging the sample with a $0.6 \% \mathrm{H}_{2} \mathrm{O} / \mathrm{He}$ mixture $(30 \mathrm{ml} / \mathrm{min})$ at $473 \mathrm{~K}$ for $1 \mathrm{~h}$ [12]. After cooling to room temperature, the sample was heated to $873 \mathrm{~K}$ at a rate of $10 \mathrm{~K} / \mathrm{min}$ under He flow (30 ml/min). The amount of $\mathrm{NH}_{3}$ desorbed was monitored by an Omnistar QMS200 mass spectrometer.

Solid state magic angle spinning nuclear magnetic resonance (MAS NMR) experiments were performed on a Varian Infinityplus-400 spectrometer. ${ }^{29} \mathrm{Si}$ MAS NMR spectra were obtained at 79.4 MHz using a $7.5 \mathrm{~mm}$ MAS probe with a spinning rate of $10 \mathrm{kHz}$. Chemical shifts were referenced to 4,4-dimethyl-4-silapentane sulfonate sodium (DSS). Four hundred scans were accumulated with a $\pi / 4$ pulse width of $2.15 \mu \mathrm{s}$ and a 4 s recycle delay. ${ }^{27} \mathrm{Al}$ MAS NMR spectra were recorded at a resonance frequency of $104.2 \mathrm{MHz}$ with a spinning rate of 10 $\mathrm{kHz}$. Chemical shifts were referenced to $\left(\mathrm{NH}_{4}\right) \mathrm{Al}\left(\mathrm{SO}_{4}\right)_{2} \cdot 12 \mathrm{H}_{2} \mathrm{O}$ at $\delta=-0.4$. The spectra were accumulated for 600 scans with $\pi / 4$ pulse width of $1.8 \mu$ s and 2 s recycle delay. Spectra deconvolution was done using the Dmfit software based on Gaussian-Lorentzian line shapes [30].

Temperature-programmed oxidation (TPO) measurements of the used samples were conducted with a U-shape microreactor. Before the experiment, the sample (100 mg) was pretreated with $\mathrm{He}(40 \mathrm{ml} / \mathrm{min})$ at $473 \mathrm{~K}$ for $1 \mathrm{~h}$. After cooling to room temperature, the sample was heated to $1073 \mathrm{~K}$ at a rate of $10 \mathrm{~K} / \mathrm{min}$ under the flow of a $20 \% \quad \mathrm{O}_{2} / \mathrm{He}$ mixture $(40$ $\mathrm{ml} / \mathrm{min}$ ) during which the $\mathrm{m} / \mathrm{e}$ intensities for 44,28 , and 18 were recorded. The $\mathrm{CO}_{2}$ and $\mathrm{CO}$ signals were calibrated by burning different weights of $\mathrm{Cu}\left(\mathrm{CO}_{3}\right) \cdot \mathrm{Cu}(\mathrm{OH})_{2} \cdot \mathrm{CO}_{2}$ contributes a fragment to the signal at $m / e=28$, and this was subtracted from the total intensity at $m / e=28$ to get the amount of CO. Also, because $\mathrm{CO}$ and $\mathrm{CO}_{2}$ showed similar curve shapes, the amount of $\mathrm{CO}$ was added to that of $\mathrm{CO}_{2}$ to simplify the analysis, which was performed in terms of carbon oxides [31].

\subsection{Catalytic test}

DME carbonylation was tested with a continuous flow fixed bed micro-reactor with an inner diameter of $8 \mathrm{~mm}$. A $100 \mathrm{mg}$ sample (40-60 mesh) was loaded into the reactor, heated to $773 \mathrm{~K}$ at a rate of $3 \mathrm{~K} / \mathrm{min}$ under $\mathrm{N}_{2}$ flow (30 ml/min), and maintained at this temperature for $1 \mathrm{~h}$. Then, the temperature was lowered to $473 \mathrm{~K}$, a DME/CO/He = 5/76/19 (V/V, 8.34 $\mathrm{ml} / \mathrm{min}$ ) mixture was introduced and the reactor was pressurized to 1.0 MPa. The effluent from the reactor was analyzed by an online gas chromatograph (Agilent 6890N) equipped with TCD and FID detector.

\section{Results and discussion}




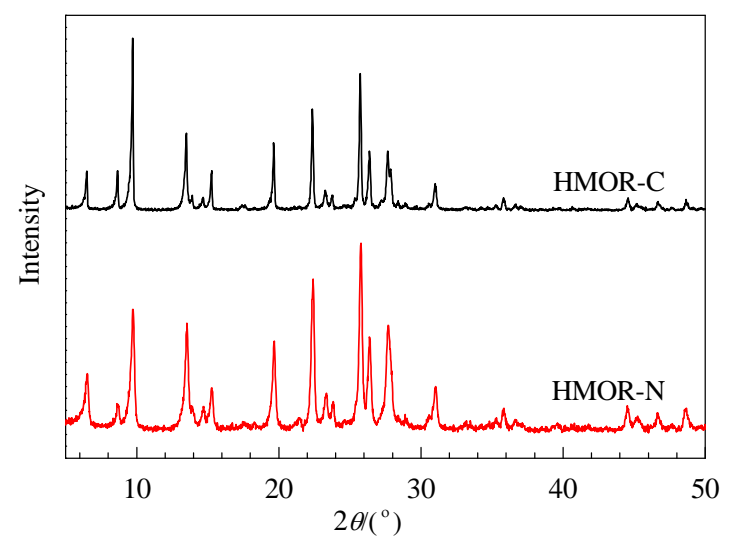

Fig. 1. XRD patterns of the mordenites.

\subsection{Structural properties of the samples}

Figure 1 shows the XRD patterns of the HMOR-C and HMOR-N samples. Both samples exhibited typical diffraction lines of mordenite zeolites (PDF number: 11-0155). The HMOR-N sample showed slightly broader diffractions due to its smaller crystallite size.

Figure 2 shows the FE-SEM and TEM images of the samples. The HMOR-C sample has a block-like morphology with average sizes of $\sim 6 \mu \mathrm{m}$ in length and $\sim 2 \mu \mathrm{m}$ in width. A few crystals with irregular shape and size of $\sim 3 \mu \mathrm{m}$ were also observed. The HMOR-N sample had a cubic crystal morphology with crystallites of 50-100 nm, which differ from the HMOR-C sample.

As shown in Table 1, the two samples had similar surface area and microporous pore volume. However, the total pore volume of HMOR-N was larger than that of HMOR-C, which can be explained by the creation of intercrystalline pores for the nanometer-sized sample.

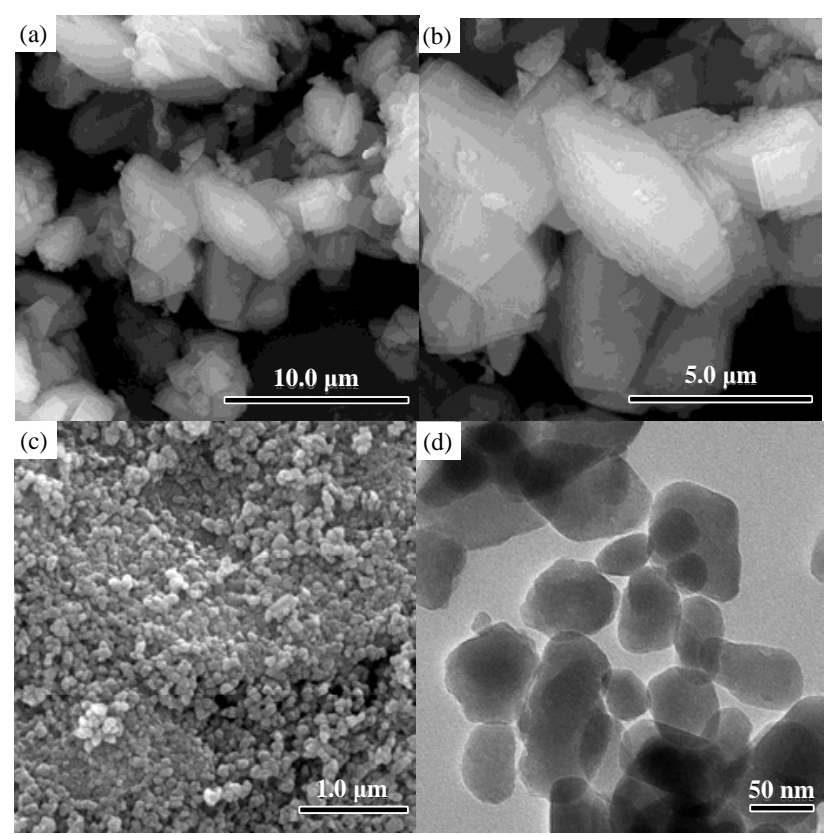

Fig. 2. FE-SEM (a, b, c) and TEM (d) images of the HMOR-C $(a, b)$ and HMOR-N (c, d) catalysts.
Table 1

Textural and structural properties of the mordenites.

\begin{tabular}{lccccc}
\hline Sample & $\begin{array}{c}A_{\text {BET }} \\
\left(\mathrm{m}^{2} / \mathrm{g}\right)\end{array}$ & $\begin{array}{c}A_{\text {external }} \\
\left(\mathrm{m}^{2} / \mathrm{g}\right)\end{array}$ & $\begin{array}{c}V_{\text {total }} \\
(\mathrm{ml} / \mathrm{g})\end{array}$ & $\begin{array}{c}V_{\text {micropore }} \\
(\mathrm{ml} / \mathrm{g})\end{array}$ & $\begin{array}{c}\mathrm{NH}_{3} \text { amount } \\
(\mathrm{mmol} / \mathrm{g})\end{array}$ \\
\hline HMOR-C & 547 & 72 & 0.298 & 0.189 & 0.71 \\
HMOR-N & 567 & 83 & 0.806 & 0.191 & 0.69 \\
\hline
\end{tabular}
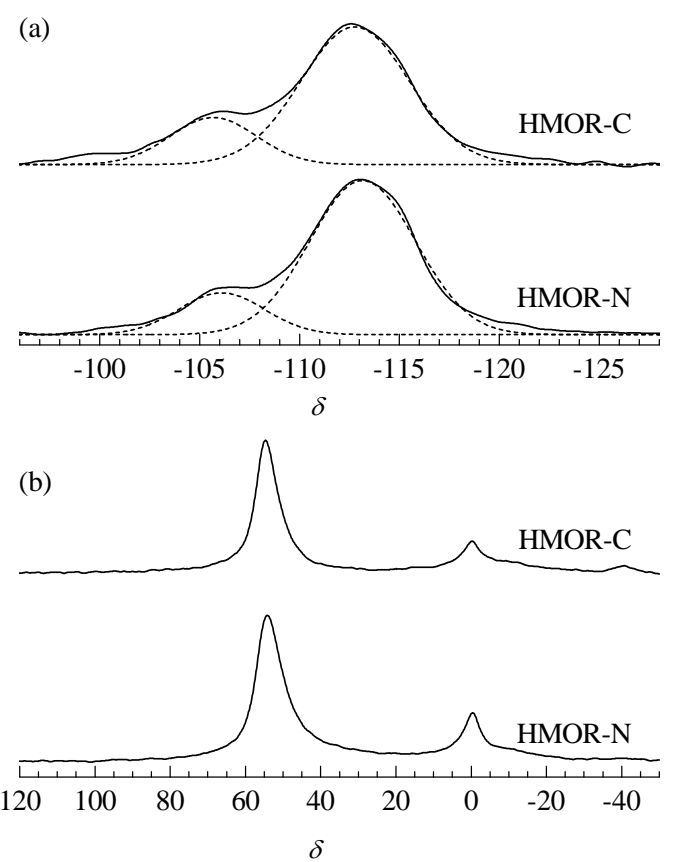

Fig. 3. ${ }^{29} \mathrm{Si}$ MAS NMR (a) and ${ }^{27} \mathrm{Al}$ MAS NMR (b) spectra of the two mordenite samples.

Figure 3 shows the NMR spectra of the two mordenites. The ${ }^{29} \mathrm{Si}$ MAS NMR spectra were deconvoluted into two Gaussian peaks at $\delta=-113$ and -107 , which were assigned to $\mathrm{Si}(0 \mathrm{Al})$ and $\mathrm{Si}(1 \mathrm{~A} 1)$ units, respectively [32]. The $\mathrm{Si} / \mathrm{Al}$ ratios were estimated to be 18 for HMOR-C and 22 for HMOR-N. In the ${ }^{27} \mathrm{Al}$ MAS NMR spectra, the intense peak at $\delta=54$ represented tetrahedrally coordinated framework $\mathrm{Al}\left(\mathrm{Al}^{\mathrm{IV}}\right)$ while the weak peak at $\delta$ $=0$ corresponded to octahedrally coordinated extra-framework $\mathrm{Al}(\mathrm{AlvI})$.

The acidic features of the samples were also characterized by $\mathrm{NH}_{3}$-TPD measurements. Usually, two distinct $\mathrm{NH}_{3}$ desorptions at low and high temperatures appeared with HMOR, corresponding to weak and strong acidic sites, respectively. However, weakly adsorbed $\mathrm{NH}_{3}$ can be removed by water vapor at about $473 \mathrm{~K}$, facilitating the quantitative determination of the strong Brönsted acidic sites [12,33,34]. As shown in Fig. 4, both samples exhibited a similar desorption peak at 530-873 K. The total amounts of Brönsted acid sites were $0.71 \mathrm{mmol} / \mathrm{g}$ for HMOR-C and $0.69 \mathrm{mmol} / \mathrm{g}$ for HMOR-N (Table 1). These results verified that the two samples had very similar acidic properties and $\mathrm{Si} / \mathrm{Al}$ ratios.

\subsection{DME carbonylation}

Figure 5(a) compares the DME conversion and product selectivity during DME carbonylation over the mordenites. With 


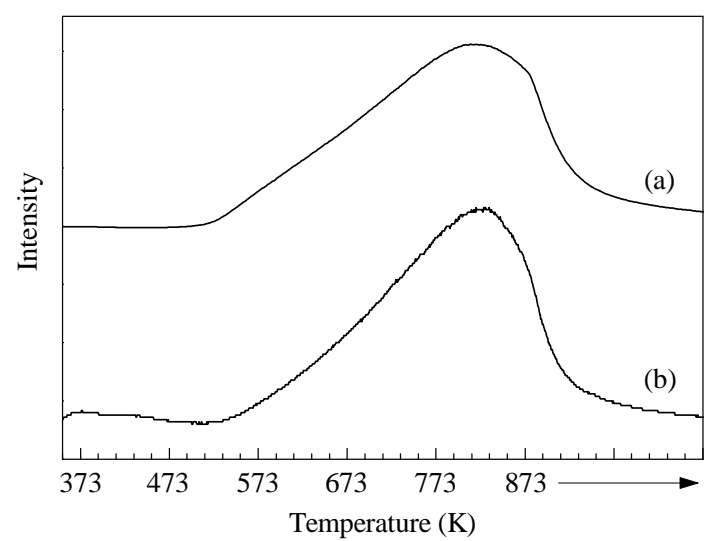

Fig. 4. $\mathrm{NH}_{3}$-TPD profiles of the HMOR-C (a) and HMOR-N (b) catalysts.

the HMOR-C catalyst, DME conversion increased from $8 \%$ at 1 $\mathrm{h}$ to the maximum of $13.7 \%$ at $4 \mathrm{~h}$, which was followed by a sharp decrease to $5 \%$ at $12 \mathrm{~h}$. The selectivity to MA decreased from $97 \%$ at $4 \mathrm{~h}$ to $75 \%$ at $12 \mathrm{~h}$, during which the selectivity to methanol and hydrocarbons (mainly methane) increased to $15 \%$ and $10 \%$, respectively. This reaction pattern confirmed that deactivation was linked with the production of methanol and hydrocarbons. With the HMOR-N catalyst, the activity was enhanced significantly. The conversion of DME reached 38\% at $2 \mathrm{~h}$, and it was maintained at this value for $3 \mathrm{~h}$. It then gradually decreased to $24 \%$ at $12 \mathrm{~h}$. The selectivity to MA was more than $98 \%$ at $5 \mathrm{~h}$, and this only slightly decreased to $93 \%$ at $12 \mathrm{~h}$ with

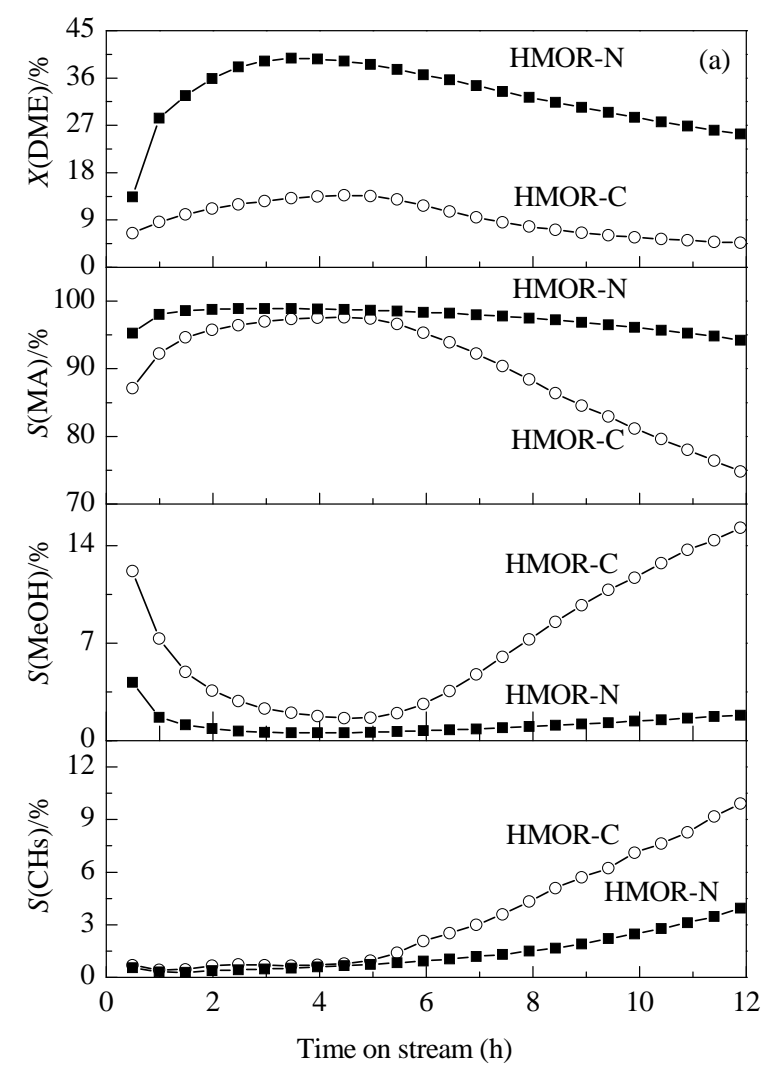

the formation of small amounts of methanol (2\%) and hydrocarbons (4\%). Figure 5(b) shows the deactivation rate constants $\left(k_{\mathrm{d}}\right)$ from DME carbonylation on the HMOR catalysts. The $k_{\mathrm{d}}$ values, calculated from the MA formation rate $\left(r_{\mathrm{MA}}\right)$ using the procedure reported in the literature $[35,36]$, were $0.21 \mathrm{~h}^{-1}$ for the HMOR-C catalyst and $0.08 \mathrm{~h}^{-1}$ for the HMOR-N catalyst. Clearly, the nanometer-sized HMOR-N catalyst had a much lower deactivation rate constant than the micrometer-sized HMOR-C catalyst.

Figure 5(c) compares the TPO profiles of the coked catalysts after running the DME carbonylation reaction for $12 \mathrm{~h}$ at $473 \mathrm{~K}$. Over the coked HMOR-C catalyst, two distinct evolution of carbon oxides appeared at 640-690 and 760-840 K. The low temperature peak is generally attributed to the combustion of soft coke, i.e., surface-bound methyl and acetyls associated with the formation of MA, while the high temperature desorption peak is ascribed to the combustion of hard coke $[12,13,37,38]$. The total amount of coke was $5.4 \mathrm{mmol} \mathrm{C} / \mathrm{g}_{\text {cat, }}$ with $20 \%$ soft coke and $80 \%$ hard coke. On the used HMOR-N catalyst, two main desorption peaks of carbon oxides at 600 and $810 \mathrm{~K}$ were also detected. However, the total amount of coke was only 3.6 mmol C/gat, containing 42\% soft coke and 58\% hard coke. Obviously, accumulated coke on the nanometer-sized HMOR, especially the hard coke, was much less than that in the micrometer-sized mordenite.

The HMOR-N catalyst showed not only much higher DME conversion and MA selectivity but also better stability during the DME carbonylation. This result confirms the reduced diffu-
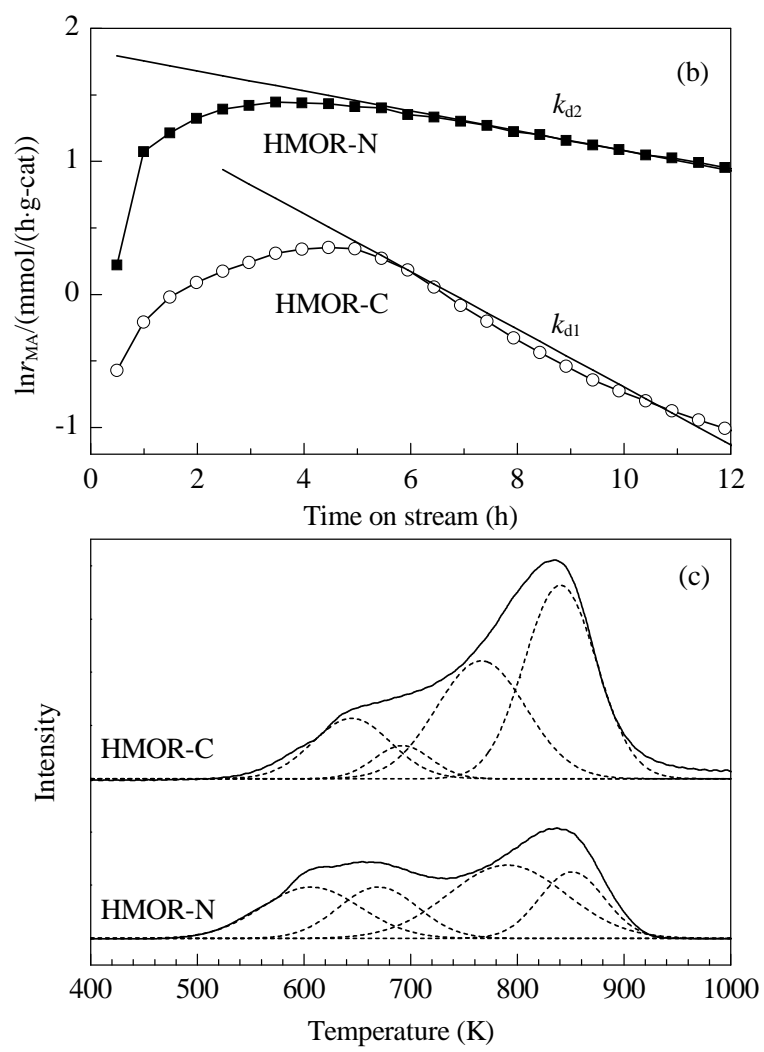

Fig. 5. DME carbonylation over the HMOR-C and HMOR-N catalysts. (a) DME conversion and product selectivity; (b) Deactivation rate constants; (c) TPO profiles of the coked catalysts. 
sion resistance in the HMOR-N catalyst. Nanometer-sized crystals offer more pore entrances and a shorter diffusion pathway than the micrometer-sized ones. On the nanometer-sized HMOR catalyst, the easy accessibility of the reactants to the active sites located in the 8-MR pores favored a higher DME conversion. Meanwhile, the much shorter diffusion pathway and more available pore entrances greatly reduced the diffusion limitation of the products and reaction intermediates, suppressing secondary reactions and the formation of coke $[18,22,39]$. In contrast, the much longer intra-crystalline diffusion pathway in the micrometer-sized crystals induced successive polymerization of the reaction intermediates and products. As a consequence, the formation of more hard coke (heavy hydrocarbons) seriously blocked the zeolite pores and caused rapid deactivation.

\section{Conclusions}

Compared to the conventional micrometer-sized mordenite, a nanometer-sized mordenite showed considerably enhanced reaction rate and long term stability in dimethyl ether (DME) carbonylation to methyl acetate (MA). Due to more pore entrances and shorter diffusion pathways, the decreased intra-crystalline diffusion limitation of the reactants and products to and from the active sites inside the nanometer-sized mordenite particles greatly promoted the conversion of DME and suppressed the deposition of coke, in particular hard coke.

\section{Acknowledgements}

BP Chemicals Limited is greatly acknowledged.

\section{References}

[1] San X G, Zhang Y, Shen W J, Tsubaki N. Energy Fuels, 2009, 23: 2843
[2] Li X G, San X G, Zhang Y, Ichii T, Meng M, Tan Y S, Tsubaki N. ChemSusChem, 2010, 3: 1192

[3] Zhang Y, San X G, Tsubaki N, Tan Y S, Chen J F. Ind Eng Chem Res, 2010, 49: 5485

[4] Cheung P, Bhan A, Sunley G J, Iglesia E. Angew Chem Int Ed, 2006, 45: 1617

[5] Blasco T, Boronat M, Concepción P, Corma A, Law D, Vidal-Moya J A. Angew Chem Int Ed, 2007, 46: 3938

[6] Cheung P, Bhan A, Sunley G J, Law D J, Iglesia E. J Catal, 2007, 245: 110

[7] Bhan A, Allian A D, Sunley G J, Law D J, Iglesia E. J Am Chem Soc, 2007, 129: 4919

[8] Boronat M, Martinez-Sanchez C, Law D, Corma A. J Am Chem Soc, 2008, 130: 16316

[9] Armitage G G, Sunley J G. EP Patent 2174713 A1. 2010

[10] Ditzel E J, Law D J, Sunley J G. WO Patent 2010067043 A1. 2010

[11] Ditzel E J, Law D J, Roberts M S. US Patent 20100130771 A1. 2010

[12] Liu J L, Xue H F, Huang X M, Wu P H, Huang S J, Liu S B, Shen W J. Chin J Catal (刘俊龙, 薛会福, 黄秀敏, 吴培豪, 黄信炅, 刘尚斌, 申文 杰. 催化学报), 2010, 31: 729

[13] Liu J L, Xue H F, Huang X M, Li Y, Shen W J. Catal Lett, 2010, 139: 33

[14] Boronat M, Martinez C, Corma A. Phys Chem Chem Phys, 2011, 13: 2603

[15] Sano T, Wakabayashi S, Oumi Y, Uozumi T. Microporous Mesoporous Mater, 2001, 46: 67

[16] Christensen C H, Schmidt I, Christensen C H. Catal Commun, 2004, 5: 543

[17] Perez-Ramirez J, Christensen C H, Egeblad K, Christensen C H, Groen J C. Chem Soc Rev, 2008, 37: 2530

[18] Holm M S, Taarning E, Egeblad K, Christensen C H. Catal Today, 2011, 168: 3

[19] Magnoux P, Rabeharitsara A, Cerqueira H S. Appl Catal A, 2006, 304: 142

[20] Ji X F, Qin Z F, Dong M, Wang G F, Dou T, Wang J G. Catal Lett, 2007, 117: 171

[21] Choi M, Na K, Kim J, Sakamoto Y, Terasaki O, Ryoo R. Nature, 2009, 461: 246

\section{Graphical Abstract}

Chin. J. Catal., 2013, 34: 1496-1503 doi: 10.1016/S1872-2067(12)60607-X

Coking on micrometer- and nanometer-sized mordenite during dimethyl ether carbonylation to methyl acetate

Huifu Xue, Xiumin Huang, Evert Ditzel, Ensheng Zhan, Meng Ma, Wenjie Shen*

Dalian Institute of Chemical Physics, Chinese Academy of Sciences, China; BP Chemicals Limited, UK
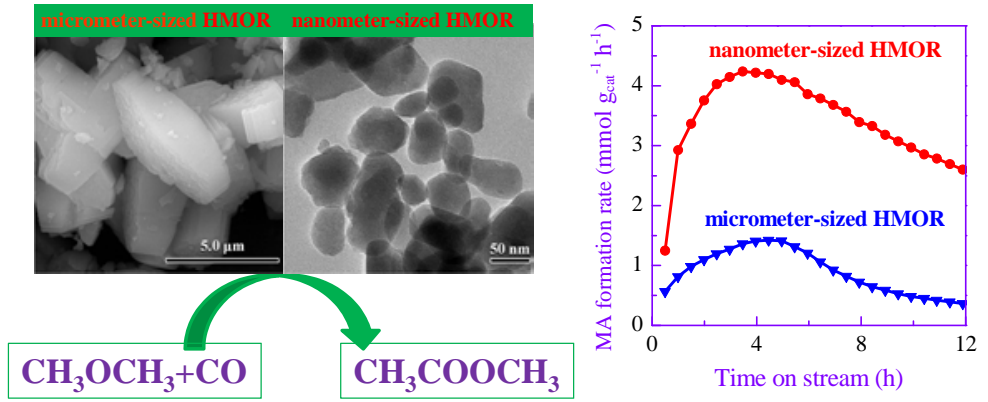

Nanometer-sized H-mordenite (HMOR) showed a much higher reaction rate and stability than micrometer-sized HMOR, resulting from the improvement of molecule transportation efficiency by reducing the crystalline size. 
[22] Mochizuki H, Yokoi T, Imai H, Watanabe R, Namba S, Kondo J N, Tatsumi T. Microporous Mesoporous Mater, 2011, 145: 165

[23] Tago T, Konno H, Sakamoto M, Nakasaka Y, Masuda T. Appl Catal A, 2011, 403: 183

[24] Rownaghi A A, Rezaei F, Stante M, Hedlund J. Appl Catal B, 2012, 119-120: 56

[25] Tago T, Konno H, Nakasaka Y, Masuda T. Catal Surv Asia, 2012, 16: 148

[26] Jang H-G, Min H-K, Lee J K, Hong S B, Seo G. Appl Catal A, 2012, 437: 120

[27] Rownaghi A A, Rezaei F, Hedlund J. Chem Eng J, 2012, 191: 528

[28] Guisnet M, Costa L, Ribeiro F R. J Mol Catal A, 2009, 305: 69

[29] Lee S H, Lee D K, Shin C H, Paik W C, Lee W M, Hong S B. J Catal, 2000, 196: 158

[30] Massiot D, Fayon F, Capron M, King I, Le Calve S, Alonso B, Durand
J O, Bujoli B, Gan Z H, Hoatson G. Magn Reson Chem, 2002, 40: 70

[31] Ma D, Wang D Z, Su L L, Shu Y Y, Xu Y D, Bao X H. J Catal, 2002, 208: 260

[32] Barras J, Klinowski J, McComb D W. J Chem Soc, Faraday Trans, 1994, 90: 3719

[33] Bagnasco G. J Catal, 1996, 159: 249

[34] Katada N, Niwa M. Catal Surv Asia, 2004, 8: 161

[35] Levenspiel O.J Catal, 1972, 25: 265

[36] Yao S D, Gu L J, Sun C Y, Li J, Shen W J. Ind Eng Chem Res, 2009, 48: 713

[37] Guisnet M, Magnoux P. Appl Catal A, 2001, 212: 83

[38] Palumbo L, Bonino F, Beato P, Bjorgen M, Zecchina A, Bordiga S. J Phys Chem C, 2008, 112: 9710

[39] Rownaghi A A, Rezaei F, Hedlund J. Microporous Mesoporous Mater, 2012, 151: 26

\title{
微米及纳米丝光沸石分子篮上二甲醚羰基化反应的积碳分析
}

\author{
薛会福 ${ }^{\mathrm{a}}$, 黄秀敏 ${ }^{\mathrm{a}}$, Evert Ditzel $^{\mathrm{b}}$, 展恩胜 ${ }^{\mathrm{a}}$,马 猛 ${ }^{\mathrm{a}}$, 申文杰 ${ }^{\mathrm{a},{ }^{*}}$ \\ a中国科学院大连化学物理研究所催化基础国家重点实验室, 辽宁大连 116023 \\ ${ }^{\mathrm{b}}$ Hull Research and Technology Centre, BP Chemicals Limited, Hull HU128DS, UK
}

\begin{abstract}
摘要: 对比研究了在传统微米尺寸和新结构纳米丝光沸石催化剂上二甲醚羰基化合成乙酸甲酯的反应行为. 结果表明, 通过减小 分子篮的尺寸到纳米水平, 可以有效提高反应物和产物到达或者脱离反应活性位的效率, 从而提高了二甲醚的转化率; 更重要的 是, 抑制了硬积碳的生成, 使催化剂保持了更高的稳定性.
\end{abstract}

关键词: 氢型丝光沸石; 二甲醚; 藏基化; 晶体尺寸；积碳

收稿日期: 2013-03-25. 接受日期: 2013-04-26. 出版日期: 2013-08-20.

*通讯联系人. 电话: (0411)84379085; 传真: (0411)84694447; 电子信箱: shen98@dicp.ac.cn

基金来源：国家重点基础研究发展计划(2013CB933100); 国家自然科学基金(20973166).

本文的英文电子版由Elsevier出版社在ScienceDirect上出版(http://www.sciencedirect.com/science/journal/18722067).

\section{1. 前言}

乙醇单独或同汽油混合已广泛用作汽油发动机燃 料. 合成气经二甲醚制乙醇是全新的技术路线, 其大概 流程为: 由合成气制得的二甲醚首先在酸性分子篮上与 $\mathrm{CO}$ 经羰基化反应生成乙酸甲酯, 后者在铜基催化剂上 加氢即可得到乙醇 ${ }^{[1-3]}$. 其中二甲醚羰基化过程是最关 键的一步. 研究发现, 氢型丝光沸石(HMOR)催化剂对该 反应具有最高的催化活性 ${ }^{[4-14]}$, 但反应过程形成的积碳 导致HMOR很快失活, 这主要是由丝光沸石结构决定的. 丝光沸石孔道主要包括十二元环 $(0.67 \mathrm{~nm} \times 0.70 \mathrm{~nm})$ 主 孔道和与之平行的八元环 $(0.28 \mathrm{~nm} \times 0.57 \mathrm{~nm})$ 孔道, 两者 通过另一个垂直的八元环孔道 $(0.34 \mathrm{~nm} \times 0.48 \mathrm{~nm}$, side pockets)相连接 ${ }^{[14,15]}$. 反应过程中, 甲氧基在八元环内以 平行于孔道轴线的方向吸附, 有利于CO攻击表面甲基生 成过度态 $\mathrm{CH}_{3} \mathrm{CO}$ *物种; 更重要的是, 其较小的孔道结构 可以稳定过渡态. 因此, 羰基化反应主要在八元环中进 行 ${ }^{[7,8,14]}$; 而十二元环内主要发生的是导致积碳生成的副
反应. 例如, 十二元环中的甲氧基可以很快地与二甲醚 反应生成大量的烃类物质 ${ }^{[14]}$. 因此, 通过抑制十二元环 内积碳的生成来提高扩散效率, 有可能提高催化剂的稳 定性.

降低扩散阻力、改善传质过程主要有两种手段: 一 是在分子篮晶体内部引入中孔 ${ }^{[16-18]}$; 二是减小晶体尺 寸, 合成纳米尺寸的分子篮晶体 ${ }^{[19-27]}$. 纳米尺寸的分子 篮对改善扩散阻力和抑制积碳生成具有很好的效果 ${ }^{[28]}$. 这是因为当分子篮晶体由微米尺寸减小到纳米尺寸后, 反应物和产物在晶体内的扩散路径显著缩短, 从而提高

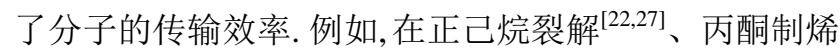

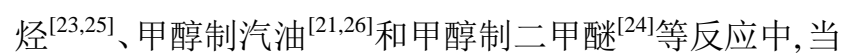
HZSM-5分子篮的尺寸减小到 $100 \mathrm{~nm}$ 时, 即可显著提高 催化剂的稳定性; 在甲苯和苯甲醚傅克酰基化反应中, 80-100 nm的Beta分子篎比传统的大尺寸 $(2-4 \mu \mathrm{m})$ Beta 分子篎具有更高的活性和稳定性 ${ }^{[20]}$.

本文对比研究了纳米尺寸和传统微米尺寸的丝光 沸石分子篮对二甲醚羰基化反应的影响, 以期阐明晶体 
尺寸对反应活性和稳定性的影响.

\section{2. 实验部分}

\section{1. 丝光沸石分子篮的制备}

采用水热法合成纳米尺寸丝光沸石 $(\mathrm{HMOR}-\mathrm{N})^{[29]}$. 将2.71 $\mathrm{g} \mathrm{Al}\left(\mathrm{NO}_{3}\right)_{3} \cdot 9 \mathrm{H}_{2} \mathrm{O}$ 和4.7 $\mathrm{g} \mathrm{Et}_{6}$-diquat-5 $(N, N, N, N$, $N^{\prime}, N^{\prime}$-六乙基-1,5-戊二胺阳离子)溶解到 $60 \mathrm{ml} \mathrm{NaOH}$ 溶 液 $(1 \mathrm{~mol} / \mathrm{L})$ 中, 搅拌过程中逐渐加入 $21.28 \mathrm{~g}$ 硅溶胶. 混 合物在室温充分搅拌 $24 \mathrm{~h}$ 后, 转移至 $100 \mathrm{ml}$ 聚四氟乙烯 内祄的搅拌釜中. 于 $433 \mathrm{~K}$ 搅拌状态下晶化 $7 \mathrm{~d}$, 所得固体 样品经过滤、用水洗涤后, 在 $383 \mathrm{~K}$ 干燥 $12 \mathrm{~h}$, 空气中 823 $\mathrm{K}$ 焙烧 $8 \mathrm{~h}$ 去除模板剂, 所得钠型丝光沸石 (Na-MOR)在 $\mathrm{NH}_{4} \mathrm{NO}_{3}$ 溶液 $(1 \mathrm{~mol} / \mathrm{L})$ 中于 $353 \mathrm{~K}$ 交换 4 次, 每次 $12 \mathrm{~h}$, 即得 到氨型丝光沸石 $\left(\mathrm{NH}_{4}-\mathrm{MOR}\right)^{[4]}$. 所得样品在 $383 \mathrm{~K}$ 干燥 12 $h, 773 \mathrm{~K}$ 焙烧 $3 \mathrm{~h}$, 得到氢型纳米丝光沸石催化剂 HMOR-N.

传统微米级氢型丝光沸石(HMOR-C)采用商品化的 钠型丝光沸石(Na-MOR-C)经离子交换制得. 于353 K用 $\mathrm{NH}_{4} \mathrm{NO}_{3}$ 溶液 $(1 \mathrm{~mol} / \mathrm{L})$ 与 $10 \mathrm{~g} \mathrm{Na}-\mathrm{MOR}-\mathrm{C}(\mathrm{Si} / \mathrm{Al}=9)$ 交换 4 次, 每次 $12 \mathrm{~h}$, 所得样品在 $383 \mathrm{~K}$ 干燥 $12 \mathrm{~h}$. 为了调节样品 的硅铝比, 取 $4 \mathrm{~g}$ 上述样品, 放入到 $200 \mathrm{ml} \mathrm{HNO}_{3}$ 溶液 (4 $\mathrm{mol} / \mathrm{L}$ )中, 在373 K 快速摚拌下处理 $10 \mathrm{~h}$, 过滤、洗涤后, 于 $383 \mathrm{~K}$ 干燥 $12 \mathrm{~h}$, 空气中 $773 \mathrm{~K}$ 焙烧 $6 \mathrm{~h}$, 得到微米尺寸的丝 光沸石催化剂HMOR-C.

\section{2. 样品的表征}

X射线衍射(XRD)在Rigaku D/MAX-2500/PC型粉末 $\mathrm{X}$ 射线衍射仪上进行, $\mathrm{Cu} K_{\alpha}$ 射线源, 管电压 $40 \mathrm{kV}$, 管电流 $100 \mathrm{~mA}$, 扫描速率 $5 \%$ min. $\mathrm{N}_{2}$ 吸附 - 脱附等温线在 Quantachrome Autosorb-1-MP型物理吸附仪上测定, 样 品预先在 $573 \mathrm{~K}$ 抽空预处理 $2 \mathrm{~h}$, 于 $77 \mathrm{~K}$ 进行实验. 场发射 扫描电镜(FE-SEM)测试在Philips FEI Quanta 200F型扫 描电镜上进行, 加速电压 $20 \mathrm{kV}$, 粉末样品附于粘有导电 胶带的样品托上. 透射电镜(TEM)测试在FEI Tecnai G2 Spirit型高分辨电镜上进行, 加速电压 $120 \mathrm{kV}$. 取少量样 品分散于无水乙醇中, 超声处理后, 滴到由铜栅固定的碳 膜上, 待乙醇挥发后观测.

$\mathrm{NH}_{3}$-程序升温脱附 $\left(\mathrm{NH}_{3}-\mathrm{TPD}\right)$ 测试在微型固定床 $\mathrm{U}$ 形石英管反应器(内径 $6 \mathrm{~mm}$ )中常压下进行. 催化剂装量 $100 \mathrm{mg}$, 在 $\mathrm{He}$ 气 $(30 \mathrm{ml} / \mathrm{min})$ 中以 $10 \mathrm{~K} / \mathrm{min}$ 升至 $773 \mathrm{~K}$, 并 恒温 $1 \mathrm{~h}$. 待体系降温至 $473 \mathrm{~K}$ 后, 引入 $10 \% \mathrm{NH}_{3} / \mathrm{He}$ 混合 气 $\left(30 \mathrm{ml} / \mathrm{min}\right.$ ) 吸附 $30 \mathrm{~min}$, 然后用 $0.6 \% \mathrm{H}_{2} \mathrm{O} / \mathrm{He}$ 混合气 $(30 \mathrm{ml} / \mathrm{min})$ 继续吹扫 $1 \mathrm{~h}$, 用 $\mathrm{H}_{2} \mathrm{O}$ 交换掉物理吸附及吸附
在 $\mathrm{L}$ 酸位上的 $\mathrm{NH}_{3}{ }^{[12]}$. 冷至室温后在 $\mathrm{He}(30 \mathrm{ml} / \mathrm{min})$ 中以 $10 \mathrm{~K} / \mathrm{min}$ 升至 $873 \mathrm{~K}$, 并恒温 $1 \mathrm{~h}$, 同 时用 Omnistar QMS200型质谱仪检测脱附的 $\mathrm{NH}_{3}$.

样品的固体核磁共振(MAS NMR)实验在Varian Infinityplus-400型核磁共振仪上进行. ${ }^{29} \mathrm{Si}$ MAS NMR谱测 定的共振频率为 $79.4 \mathrm{MHz}, \pi / 4$ 脉冲宽度 $2.15 \mu \mathrm{s}$, 脉冲重 复周期 $4 \mathrm{~s}, 7.5 \mathrm{~mm}$ MAS probe旋转速度 $10 \mathrm{kHz}$, 累加 400 次. 以4,4-二甲基-4-硅戊烷磺酸钠盐为参标. ${ }^{27} \mathrm{Al} \mathrm{NMR}$ 谱测定的共振频率为 $104.2 \mathrm{MHz}, \pi / 4$ 脉冲宽度 $1.8 \mu \mathrm{s}$, 脉 冲重复周期 $2 \mathrm{~s}, 7.5 \mathrm{~mm}$ MAS probe旋转速度 $10 \mathrm{kHz}$, 累加 600 次. 化学位移以十二水合硫酸铝氨 $(\delta=-0.4)$ 校正. ${ }^{29} \mathrm{Si}$ 谱用Dmfit软件, 以高斯-洛仑兹线型模拟解叠 ${ }^{[30]}$.

反应后样品的程序升温氧化(TPO)测试在微型固定 床U形石英管反应器(内径 $6 \mathrm{~mm}$ )中进行. $100 \mathrm{mg}$ 积碳样 品在 $\mathrm{He}(40 \mathrm{ml} / \mathrm{min})$ 中于 $473 \mathrm{~K}$ 预处理 $1 \mathrm{~h}$, 然后冷却至室 温, 切换为 $20 \% \mathrm{O}_{2} / \mathrm{He}$ 混合气体, 以 $10 \mathrm{~K} / \mathrm{min}$ 升至 $1073 \mathrm{~K}$, 过程中用质谱记录 $m / e=44,28$ 和 18 的信号变化. 其中 $\mathrm{CO}_{2}$ 和 $\mathrm{CO}$ 信号通过燃烧不同质量的碱式碳酸铜 $\left(\mathrm{Cu}\left(\mathrm{CO}_{3}\right) \cdot \mathrm{Cu}(\mathrm{OH})_{2}\right)$ 校准. 在计算 $\mathrm{CO}$ 时, 需扣除 $\mathrm{CO}_{2}$ 对 $\mathrm{CO}$ $(m / e=28)$ 的贡献. 另外将 $\mathrm{CO}$ 曲线按比例添加到 $\mathrm{CO}_{2}$ 曲线 中, 统称为碳氧物种 ${ }^{[31]}$.

\section{3. 催化剂的评价}

催化剂的活性测试在内径为 $8 \mathrm{~mm}$ 的不锈钢微型固 定床反应器中进行. $100 \mathrm{mg}$ 催化剂(40 60目)在 $\mathrm{N}_{2}$ 气(30 $\mathrm{ml} / \mathrm{min})$ 中以 $3 \mathrm{~K} / \mathrm{min}$ 升至 $773 \mathrm{~K}$, 并恒温 $1 \mathrm{~h}$ 预处理后, 降 温至 $473 \mathrm{~K}$, 引入组分为二甲醚 $/ \mathrm{CO} / \mathrm{He}=5 / 76 / 19$ (体积 比, $8.34 \mathrm{ml} / \mathrm{min}$ ) 的反应气, 并加压至 $1 \mathrm{MPa}$. 反应产物用 配备了TCD和FID检测器的Agilent 6890N型气相色谱仪 在线分析.

\section{3. 结果与讨论}

\section{1. 样品结构和性质表征}

图1是HMOR-C和HMOR-N两个样品的XRD谱. 由 图可见, 两样品均出现了典型丝光沸石型分子篮(PDF\# 11-0155)的特征衍射峰, 其中HMOR-N样品XRD衍射峰 明显宽化,表明其具有较小的晶体尺寸.

图 2 是它们的 FE-SEM和 TEM照片. 可以看出, HMOR-C具有传统的大块状晶体结构, 长度和宽度分别 约为 6 和 $2 \mu \mathrm{m}$, 另外还有一些尺寸为 $3 \mu \mathrm{m}$ 左右形状不规 则的晶体; 而HMOR-N样品主要为50 100 nm的近似立 方体晶体。

由表1数据可见,两个样品的比表面积和微孔体积 
并没有很大差异. 但是, HMOR-N样品具有更大的孔体 积, 这是因为纳米尺寸的样品可以产生更多的晶间孔.

图3(a) 是HMOR-C和HMOR-N样品的 ${ }^{29} \mathrm{Si}$ NMR 谱, 可被拟合成两个共振峰, 分别位于 $\delta=-113$ 和 -107 处, 可 分别归属为 $\mathrm{Si}(0 \mathrm{Al})$ 和 $\mathrm{Si}(1 \mathrm{~A} 1)^{[32]}$. 根据核磁共振峰面积定 量可知, HMOR-C和HMOR-N的骨架 Si/Al比分别约为 18 和22. 图3(b)是两个样品的 ${ }^{27} \mathrm{Al}$ MAS NMR谱, 在 $\delta=54$ 处 相对较强的峰一般归属为四配位的骨架铝 $\left(\mathrm{Al}^{\mathrm{IV}}\right)$, 而 $\delta=0$ 处相对较弱的峰则是八配位的非骨架铝 $\left(\mathrm{Al}^{\mathrm{VI}}\right)$.

图4为HMOR-C和HMOR-N两个样品的 $\mathrm{NH}_{3}$-TPD谱. 对于氢型丝光沸石, 其 $\mathrm{NH}_{3}-\mathrm{TPD}$ 脱附曲线通常会在低温 区和高温区有两个 $\mathrm{NH}_{3}$ 脱附峰, 分别对应于弱酸位和强 酸位吸附 $\mathrm{NH}_{3}$ 的脱附. 其中, 弱吸附氨可以被水蒸气选择 性移除, 而强酸位上吸附的氨气被保留 ${ }^{[12,33,34]}$, 通过这种 方法, 可以对分子篮B酸位进行定量. 如图4所示, 两个样 品均在530 873 K有一个脱附峰, 进一步通过计算可得, HMOR-C和HMOR-N样品总的B酸分别约为 0.71 和 0.69 $\mathrm{mmol} / \mathrm{g}$, 可见两个样品所含的B酸量非常接近.

\section{2. 二甲醚羰基化反应性能}

图5(a)比较了两种催化剂上二甲醚羰基化反应性能 随时间的变化. 由图可见, 在HMOR-C催化剂上, 二甲醚 转化率从 $1 \mathrm{~h}$ 时的 $8 \%$ 逐渐增至 $4 \mathrm{~h}$ 时的 $13.7 \%$; 至 $12 \mathrm{~h}$ 后, 二甲醚转化率降至 $5 \%$, 同时乙酸甲酯的选择性也由 $97 \%$ (4 h) 降至75\% (12 h), 而甲醇和烃类(主要为甲烷)的选择 性则分别增加到 $15 \%$ 和 $10 \%$. 这表明二甲醚羰基化反应 的失活过程伴随甲醇和烃类物质的生成. 比较而言, HMOR-N催化剂活性明显提高: 反应 $2 \mathrm{~h}$ 后, 二甲醚转化 率可达 $38 \%$, 随后经历了约 $3 \mathrm{~h}$ 的稳定期, $12 \mathrm{~h}$ 后二甲醚的 转化率降至 $24 \%$. 反应过程中, 乙酸甲酯的选择性由 $5 \mathrm{~h}$ 时的 $98 \%$ 缓慢减小到 $12 \mathrm{~h}$ 时的 $93 \%$, 甲醇和烃类的选择性 分别增大到 $2 \%$ 和 $4 \%$. 图5(b)示出了两个样品的失活速 率常数 $\left(k_{\mathrm{d}}\right)$, 该常数通过对乙酸甲酯的生成速率进行处理 得出 ${ }^{[35,36]}$. 可见, HMOR-C和HMOR-N催化剂的失活速 率常数分别为 0.21 和 $0.08 \mathrm{~h}^{-1}$, 显然, 纳米尺寸的HMOR-N 催化剂失活速率常数更小. 图5(c)为两个催化剂在 $473 \mathrm{~K} 反$ 应 $12 \mathrm{~h}$ 后积碳样品 的 TPO谱. 对于积碳的HMOR-C催化剂, 在 640 690和 760 840 K温度区间内有两个碳氧物种脱附峰. 其中, 低 温脱附峰通常被归属为软积碳的燃烧物种, 主要为表面 键合的甲氧基和乙酰基中间体物种; 而高温峰则被归属 为硬积碳物种的燃烧 ${ }^{[12,13,37,38]}$. 可见, HMOR-C样品上的 积碳量约是 $5.4 \mathrm{mmol} \mathrm{C} / \mathrm{g}_{\mathrm{cat}}$, 其中软积碳和硬积碳分别占 $20 \%$ 和 $80 \%$. 积碳的HMOR-N催化剂在 600 和 $810 \mathrm{~K}$ 也有 两个碳氧物种的脱附峰, 对应的积碳量仅有 $3.6 \mathrm{mmol}$ $\mathrm{C} / \mathrm{g}_{\text {cat }}$, 其中软积碳和硬积碳分别占 $42 \%$ 和 $58 \%$. 显然, 纳 米尺寸HMOR-N催化剂上的积碳量特别是硬积碳比微 米尺寸HMOR-C样品上的少得多.

纳米尺寸的HMOR-N在催化二甲醚羰基化过程中, 其稳定性显著提高, 同时提高了二甲醚的转化率和乙酸 甲酯的选择性. 这可能是由于HMOR-N催化剂具有更高 的扩散效率. 相比于微米尺寸的催化剂, 纳米尺寸的 HMOR催化剂可以提供更多的孔道入口和更短的扩散 路径, 使得纳米尺寸HMOR催化剂上八元环活性位更容 易接近, 从而提高了二甲醚转化率; 而且, 更多的孔道入 口和更短的扩散路径有利于反应中间体和产物的扩散, 可以有效抑制二次反应的发生和积碳的生成 ${ }^{[18,22,39]}$. 相 反, 微米尺寸催化剂上较长的晶内扩散路径可能会导致 反应中间体和产物进一步发生聚合反应, 形成更多的硬 积碳(大分子烃类物质)堵塞分子篮孔道, 导致催化剂快 速失活.

\section{4. 结论}

与微米尺寸的丝光沸石催化剂HMOR-C相比, 纳米 尺寸的HMOR-N样品在羰基化反应时具有更高的催化 活性和优异的稳定性. 这是因为纳米尺寸的丝光沸石样 品可以提供更多的孔道入口和更短的扩散路径, 有利于 反应物和产物到达或者脱离分子篮孔道中的活性位, 进 而提高了催化剂活性, 同时抑制了积碳, 尤其是硬积碳 物种的形成.

致谢 感谢BP化学有限公司对本项目的支持. 